\title{
Processing of Sulfide Copper-Nickel Ores from the Deposits in Murmansk Region by Heap Leaching
}

\author{
Elena Yanishevskya ${ }^{1}\left(\mathbb{D}\right.$, Nadezhda Fokina $^{1}$, Ekaterina Selivanova ${ }^{2}\left(\mathbb{D}\right.$, Alena Kompanchenko ${ }^{2}(\mathbb{D}$, \\ Dmitriy Makarov ${ }^{1}$ and Andrey Goryachev ${ }^{1, *}$ \\ 1 Institute of North Industrial Ecology Problems, Kola Science Centre of the Russian Academy of Sciences, \\ Fersman St., 14a, 184209 Apatity, Russia; drygina_es@mail.ru (E.Y.); n.fokina@ksc.ru (N.F.); \\ mdv_2008@mail.ru (D.M.) \\ 2 Geological Institute, Kola Science Centre of the Russian Academy of Sciences, Fersman St., 14, \\ 184209 Apatity, Russia; selivanova@geoksc.apatity.ru (E.S.); komp-alena@yandex.ru (A.K.) \\ * Correspondence: a.goryachev@ksc.ru; Tel.: +7-8155579144
}

Citation: Yanishevskya, E.; Fokina, N.; Selivanova, E.; Kompanchenko, A.; Makarov, D.; Goryachev, A.

Processing of Sulfide Copper-Nickel Ores from the Deposits in Murmansk Region by Heap Leaching. Minerals 2021, 11, 820. https://doi.org/ $10.3390 / \min 11080820$

Academic Editor: Jean-François Blais

Received: 6 July 2021

Accepted: 27 July 2021

Published: 28 July 2021

Publisher's Note: MDPI stays neutral with regard to jurisdictional claims in published maps and institutional affiliations.

Copyright: (c) 2021 by the authors. Licensee MDPI, Basel, Switzerland. This article is an open access article distributed under the terms and conditions of the Creative Commons Attribution (CC BY) license (https:// creativecommons.org/licenses/by/ $4.0 /)$.

\begin{abstract}
The feasibility of processing low-grade copper-nickel ores by heap bioleaching was investigated. It was found that an iron-oxidizing strain of acidophilic microorganisms, Acidithiobacillus ferrivorans, is effective in the leaching of sulfide ores from the deposits in Russia's Murmansk region. Sulfide mineralization of the studied mineral feeds was described using the methods of X-ray phase analysis and optical microscopy. In the process of leaching, the $\mathrm{pH}$ and Eh values and the concentrations of ferric and ferrous iron, nickel, and copper ions were monitored. By the end of the experiment, $16.5 \%$ of nickel and $7.5 \%$ of copper was recovered from the ore of the Allarechensk technogenic deposit, while $22.5 \%$ of nickel and $12.7 \%$ copper were recovered from the ore of the Nud II deposit. By silicate analysis of the solid phase, patterns of ore chemistry change were described during the process of bioleaching.
\end{abstract}

Keywords: bioleaching; sulfide ores; non-ferrous metals; technogenic waste; acidophilic microorganisms

\section{Introduction}

One of the most important areas of ongoing research is developing fundamentally new methods for the concentration of sulfide minerals in Russia's Arctic. Major resources of key minerals are concentrated in Russia's Murmansk Region, and multiple sulfide copper-nickel deposits have been found there. The nickel province of the Kola Peninsula is located in the eastern part of the Baltic Shield [1].

The Murmansk region is characterized by harsh climatic conditions, with an average annual temperature of $0.2{ }^{\circ} \mathrm{C}$. The average annual air temperature decreases from $0{ }^{\circ} \mathrm{C}$ on the coast of the Barents and White Seas to $-2{ }^{\circ} \mathrm{C}$ in the inland areas of the peninsula and down to $-3-4{ }^{\circ} \mathrm{C}$ in mountainous areas [2]. The region's ecosystems are fragile and have relatively low resilience to anthropogenic impact. In this context, the intensive development of the mining industry in the region has led to a significant deterioration of the natural environment. Changes are observed in the surface water hydrochemistry, the chemical composition of bottom sediments and soils, and the structural and functional organization of biotic communities [3].

One of the reasons for these transformations is the pollution of ecosystems with ions of copper and nickel, caused by the incomplete development of copper-nickel deposits and the accumulation of concentration tailings [4]. To minimize the negative impacts, new technology needs to be developed that can efficiently process low-grade ores and industrial waste.

Microorganism bioleaching of minerals is an evolving technology with an important potential to add value to the mining industry with the capacity to offer economic, social, and 
attractive environmental benefits to all associates. Bioleaching is a simple, environmentally friendly, and cost-effective method of processing sulfide mineral feeds [5-7]. This is due to the fact that sulfide deposits are a natural habitat for acidophilic microorganisms that oxidize iron and sulfur [8]. This method is promising in terms of processing various mineral feeds-low-grade ores, tailings dumps, fine concentration tailings, and other industrial waste-containing non-ferrous and precious metals. This process has been successfully applied in practice in a variety of climatic conditions in regions such as the South American Andes, the Arctic, and tropical regions.

Heap bioleaching has performed well in the subarctic zone, where the average annual temperature is $1.3{ }^{\circ} \mathrm{C}[9,10]$. Polymetallic ore from the Talvivaara deposit was processed using indigenous communities of microorganisms that are capable of actively oxidizing sulfides at high concentrations of nickel $(2.5 \mathrm{~g} / \mathrm{L})$, copper $(0.3 \mathrm{~g} / \mathrm{L})$, aluminium $(10 \mathrm{~g} / \mathrm{L})$, zinc $(4 \mathrm{~g} / \mathrm{L})$, magnesium $(1.2 \mathrm{~g} / \mathrm{L})$, and cobalt $(0.08 \mathrm{~g} / \mathrm{L})$. The process was run year-round, which allowed the operation to function for several years. Later, due to a process leak and environmental pollution, the operation had to be shut down.

The purpose of this study was to establish the possibility of processing Murmansk Region's low-grade sulfide ores, and anthropogenic mineral feeds using the method of heap bioleaching.

\section{Materials and Methods}

Sulfide copper-nickel ores from the Allarechensk technogenic deposit (TD) and the Nud II deposit were used in this study. The Allarechensk technogenic deposit is located in the Pechenga district of Russia's Murmansk region and is a rock dump composed of the mining waste from the primary Allarechensk sulfide copper-nickel deposit. The rock dump holds 6.7 million $\mathrm{m}^{3}$ of rock, mainly gneisses, granite gneisses, amphibolites, and mineralized host rocks. In the Allarechensk TD, the currently prevailing ore type is disseminated ores held in serpentinites.

The bulk of the ore in the Allarechensk TD is found in the range of $10-150 \mathrm{~mm}$. The grades of nickel, copper, and cobalt in the disseminated ores vary, respectively, from $7.9 \%, 4.9 \%$, and $0.12 \%$ (in high-grade ores) to $0.2 \%, 0.12 \%$, and $0.008 \%$ (in low-grade ores). Average grades found in the rock dump: nickel $1.57 \%$, copper $1.34 \%$ and cobalt $0.021 \%$. As the grade of commercial minerals decreases, the proportion of silicate nickel tends to increase. For instance, in high-grade ores, silicate nickel accounts for $11 \%$ of the total nickel, while in low-grade ores, its share is $25 \%$.

The Nud II deposit lies in the norite rocks of the eastern part of Monchepluton and is associated with the spread of the critical horizon. The ore minerals found in the Nud II deposit include pyrrhotite (40-50\%), chalcopyrite (20-30\%), pentlandite (10-15\%), and pyrite (5-10\%). In addition, magnetite is present in noticeable quantities (10-30\%). Allarechensk TD and Nud II deposits are characterized by the fact that both high-grade and run-of-mine ores support conventional concentration methods. Low-grade ores incur great losses during flotation due to the high proportion of silicate nickel.

For laboratory experiments on heap bioleaching, a psychrotolerant iron-oxidizing acidophilic strain, Acidithiobacillus ferrivorans NO-37, was chosen. This microorganism was isolated from the dump effluent of the Allarechensk TD. A characteristic feature of the strain is the temperature range of oxidation of sulfide minerals from 4 to $37^{\circ} \mathrm{C}$, with an optimal temperature of $20-30{ }^{\circ} \mathrm{C}$ [11].

The ore was ground to a size range of $2-5 \mathrm{~mm}$ and then loaded into glass columns with a diameter of $2.7 \mathrm{~cm}$. The weight of the ore sample from the Allarechensk TD was $800 \mathrm{~g}$, while the one from the Nud II deposit was $200 \mathrm{~g}$. The experiments were carried out using a mineral nutrient medium containing nitrogen and phosphorus salts $(\mathrm{g} / \mathrm{L})$ : $\left(\mathrm{NH}_{4}\right)_{2} \mathrm{SO}_{4}-3.0$; $\mathrm{KCl}-0.1 ; \mathrm{MgSO}_{4} \times 7 \mathrm{H}_{2} \mathrm{O}-0.5 ; \mathrm{K}_{2} \mathrm{HPO}_{4}-0.5, \mathrm{FeSO}_{4}-44.22$, with initially approximately $1 \times 10^{8}$ cell $/ \mathrm{mL}$ of the microorganisms. The ore in the columns was irrigated with a solution at an S:L ratio of $4: 1$ for 80 days, and the ambient temperature was $19^{\circ} \mathrm{C}$. 
Throughout the experiment, the $\mathrm{pH}$ and Eh values of the pregnant liquors and the concentrations of ferric and ferrous iron, nickel, and copper ions were monitored. The $\mathrm{pH}$ and Eh values were measured using an I-160MI ion meter (Izmeritelnaya tekhnika Co. Ltd., Moscow, Russia). The concentrations of $\mathrm{Fe}^{3+}$ and $\mathrm{Fe}^{2+}$ were measured by titration using Trilon B. The concentration of nickel and copper in the pregnant liquors was measured by atomic absorption spectrometry with electrothermal atomization (by following the standard PND F 14.1:2:4.140-98). The measurement error did not exceed 5\%. The recoveries were calculated based on the concentrations of metals in pregnant solutions and the initial content of metals in the ore sample.

These measurements made it possible to assess the activity of the microorganisms responsible for the bioleaching process since the oxidation of sulfide, iron, copper, and nickel ions accumulate in a liquid medium, forming sulfuric acid. This, in turn, leads to a decrease in $\mathrm{pH}$ and a high concentration ratio of $\mathrm{Fe}^{3+} / \mathrm{Fe}^{2+}$ ions, which is typical for active bioleaching processes and leads to an increase in Eh. In addition, the recovery of non-ferrous metals was calculated from the concentration of metals in the liquid phase.

Ore chemistry was studied using an ELAN 9000 DRC-e inductively coupled plasma mass spectrometer (PerkinElmer Inc., Waltham, MA, USA). The mineral compositions of the primary and experimental samples were measured by powder X-ray diffraction techniques using the DRON-2.0 instrument (JSC Burevestnik, Saint Petersburg, Russia) with a $\mathrm{Cu}-\mathrm{K} \alpha$ radiation source.

\section{Results and Discussion}

X-ray phase analysis revealed that in the initial Allarechensk TD ore, the predominant sulfide minerals are pyrrhotite and pentlandite, while chalcopyrite is less common (Figure 2a). The ore is characterized by a significant proportion of silicates represented by amphibole and serpentine. Reflections of the same sulfides are characteristic of the Nud II ore. A higher chalcopyrite content was observed in the Nud II ore compared to the Allarechensk TD ore (Figure 4a). Reflections of serpentine and amphibole were observed among nonmetallic minerals.

Using microscopic analysis, it was found that the disseminated sulfide in the low-grade copper-nickel ores is represented by both individual sulfide grains and intergrowths thereof (Figure 1). The main ore minerals are pyrrhotite, pentlandite, and chalcopyrite. Magnetite is often found in combination with these, as shown in Figure 1a. Finely disseminated sulfides (pyrrhotite, pentlandite) were also found in silicates (Figure 1b-d).

After leaching for 80 days, reflections of sulfides still appeared in the Allarechensk TD ore (Figure 2). That was due to the short duration of the experiment. After leaching for 80 days, we continued to record reflections of sulfides (Figure 2b), due to the short duration of the experiment. In the global industry practice, the process of heap bioleaching runs continuously for several years. Visually, the ore particles are sintered, covered with a crust (commonly iron hydroxides), and then begin to peel off and crumble. Chemically, sulfides transform into sulfates and hydroxides. This led to a certain decrease in the solution filtration intensity starting from the middle of the experiment. 


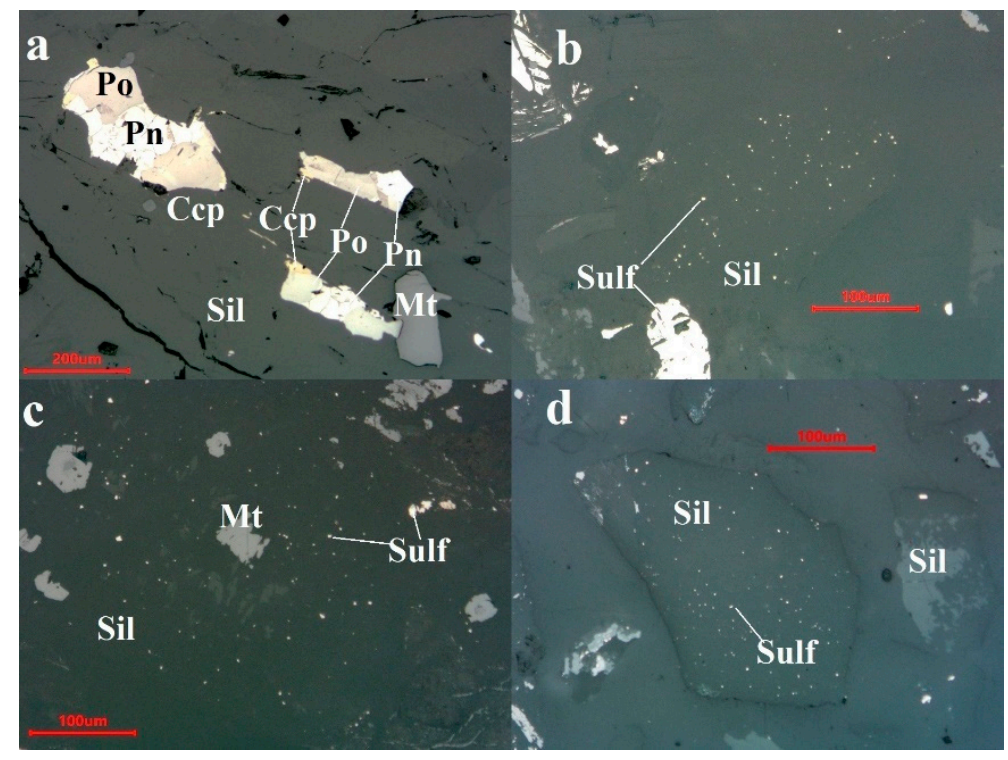

Figure 1. An example of low-grade disseminated sulfide copper-nickel ores of the Murmansk Region: (a) Large intergrowths of several sulfides and magnetite in a silicate; (b-d) large intergrowths of sulfides and finely disseminated sulfides in silicate. Images taken with reflected polarized light. Ccp: chalcopyrite; Mt: magnetite; Pn: pentlandite; Po: pyrrhotite; Sil: silicate mineral; Sulf: sulfide.

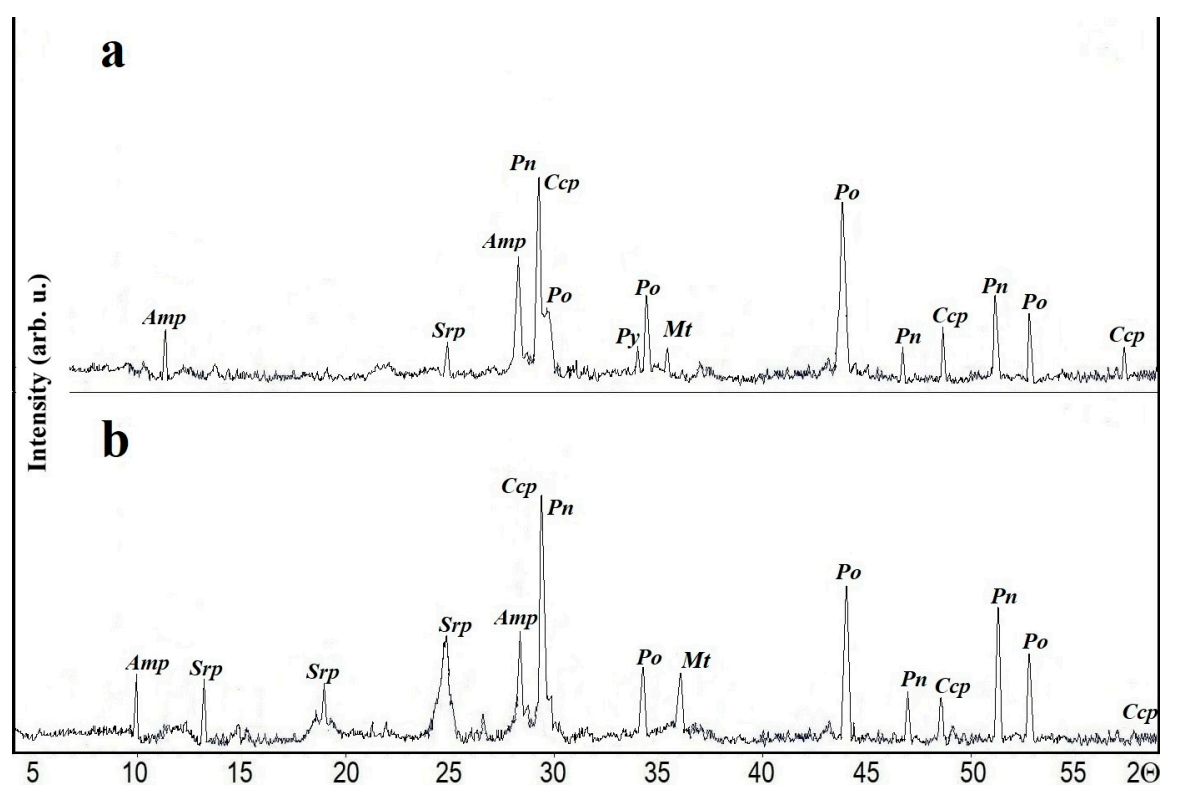

Figure 2. X-ray diffraction pattern of the Allarechensk TD samples: (a) feed ore; (b) ore after leaching. Amp: amphibole; Srp: serpentine; Po: pyrrhotite; Pn: pentlandite; Ccp: chalcopyrite; Mt: magnetite.

In the course of the bioleaching experiments on the Allarechensk TD ore, 16.5\% of nickel and $7.5 \%$ of copper were recovered after 80 days (Figure 3c). The maximum concentration of nickel in the solution was noted on the 22nd day of the experiment, which amounted to $1557 \mathrm{mg} / \mathrm{L}$, while the average concentration during the experiment was $680 \mathrm{mg} / \mathrm{L}$ (Figure 3a). The maximum concentration of copper was noted on the 30th day of the experiment $(211 \mathrm{mg} / \mathrm{L})$ with an average concentration of $84 \mathrm{mg} / \mathrm{L}$. It should be noted that the concentration of nickel ions $\left(\mathrm{Ni}^{2+}\right)$ exceeded the concentration of copper ions $\left(\mathrm{Cu}^{2+}\right)$, which is primarily due to the fact that the chalcopyrite in the ore is more resistant to oxidation. In addition, the chemistry of the Allarechensk TD ore samples showed the intensive leaching of cobalt (Table 1), which is also of practical interest due to the significant 
market demand for this metal. The only cobalt concentrator in the ores is pentlandite, in addition to violarite in oxidized ores.
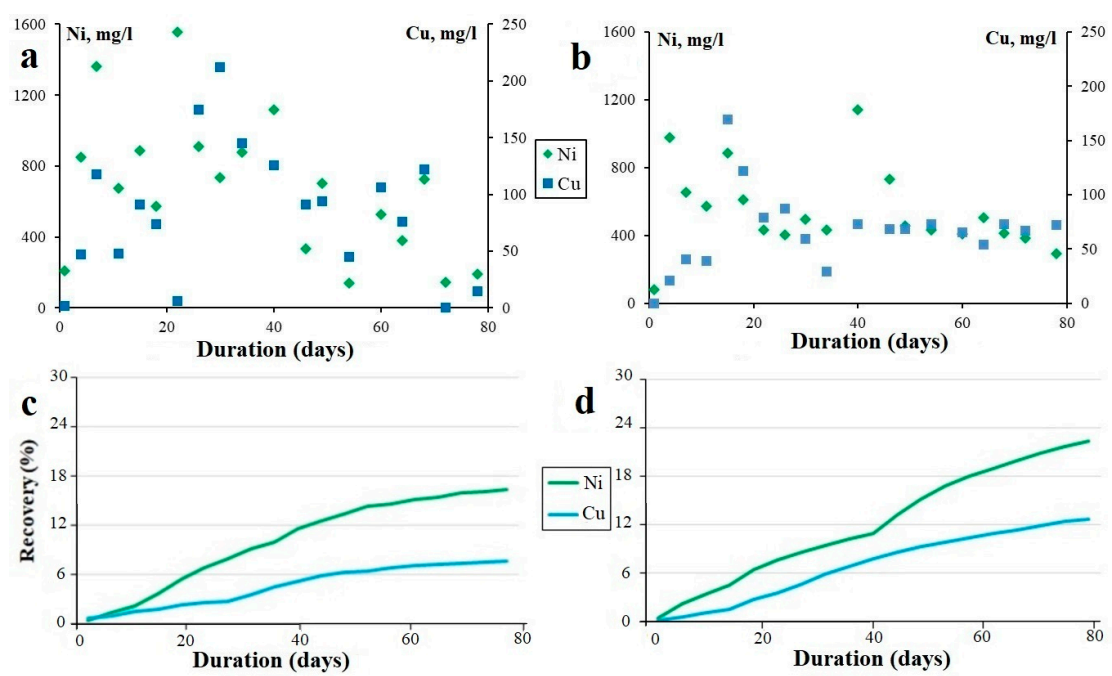

Figure 3. The concentration of metals in pregnant liquors during ore bioleaching: (a) Allarechensk TD, (b) Nud II. Recovery of metals into solution during the experiment: (c) Allarechensk TD, (d) Nud II.

Table 1. Chemical composition of the Allarechensk TD ore.

\begin{tabular}{ccccccccccccc}
\hline & $\mathrm{Na}_{2} \mathrm{O}$ & $\mathbf{M g O}$ & $\mathrm{Al}_{2} \mathrm{O}_{3}$ & $\mathrm{SiO}_{2}$ & $\mathbf{S}$ & $\mathrm{CaO}$ & $\mathrm{TiO}_{2}$ & $\mathrm{Cr}_{2} \mathrm{O}_{3}$ & $\mathrm{Fe}_{2} \mathrm{O}_{3}$ & $\mathrm{CoO}$ & $\mathbf{N i O}$ & $\mathrm{CuO}$ \\
\hline Feed ore & 0.07 & 9.38 & 1.68 & 14.0 & 29.8 & 1.10 & 0.43 & 0.15 & 30.3 & 0.41 & 5.41 & 4.93 \\
\hline Ore after leaching & 0.06 & 8.64 & 0.61 & 12.9 & 26.7 & 0.98 & 0.39 & 0.13 & 27.1 & 0.37 & 4.72 & 4.80 \\
\hline
\end{tabular}

The $\mathrm{pH}$ value of the pregnant liquors varied during the experiment from 1.9 to 2.2, while the redox potential ranged from 471 to $582 \mathrm{mV}$. The concentration of $\mathrm{Fe}^{3+}$ at the beginning of the experiment was $9.0 \mathrm{~g} / \mathrm{L}$ and increased by the end of the experiment to $15.0 \mathrm{~g} / \mathrm{L}$, while the concentration of $\mathrm{Fe}^{2+}$ decreased from $3.0 \mathrm{~g} / \mathrm{L}$ to $0.9 \mathrm{~g} / \mathrm{L}$. The content of sulfur in the ore sample decreased by $10.4 \%$, which indicates the activity of microorganisms (Table 1).

In the course of bioleaching of the copper-nickel ore from the Nud II deposit, the maximum concentration of nickel in the solution was noted on the 40th day, which equivalently amounted to $1140 \mathrm{mg} / \mathrm{L}$, while the average concentration of nickel in the solution during the experiment was $542 \mathrm{mg} / \mathrm{L}$ (Figure 3b). The maximum concentration of copper was noted on the 15th day of the experiment $(169 \mathrm{mg} / \mathrm{L})$ with an average concentration of $66 \mathrm{mg} / \mathrm{L}$. The leaching kinetics of non-ferrous metals from the Nud II ore was characterized by a decrease in recoveries at the middle of the experiment, followed by an increase in the concentrations. Thus, the concentration of copper on the 35th day of the experiment decreased to $29 \mathrm{mg} / \mathrm{L}$. Over the entire study period, $22.5 \%$ of nickel and $12.7 \%$ of copper were recovered from the ore (Figure 3d). The reflections of sulfides still appear after leaching (Figure 4). The extraction of the metals from pregnant solutions can be carried out following the example of the Talvivaara company, where hydrogen sulfide was used for the precipitation of the metal. 


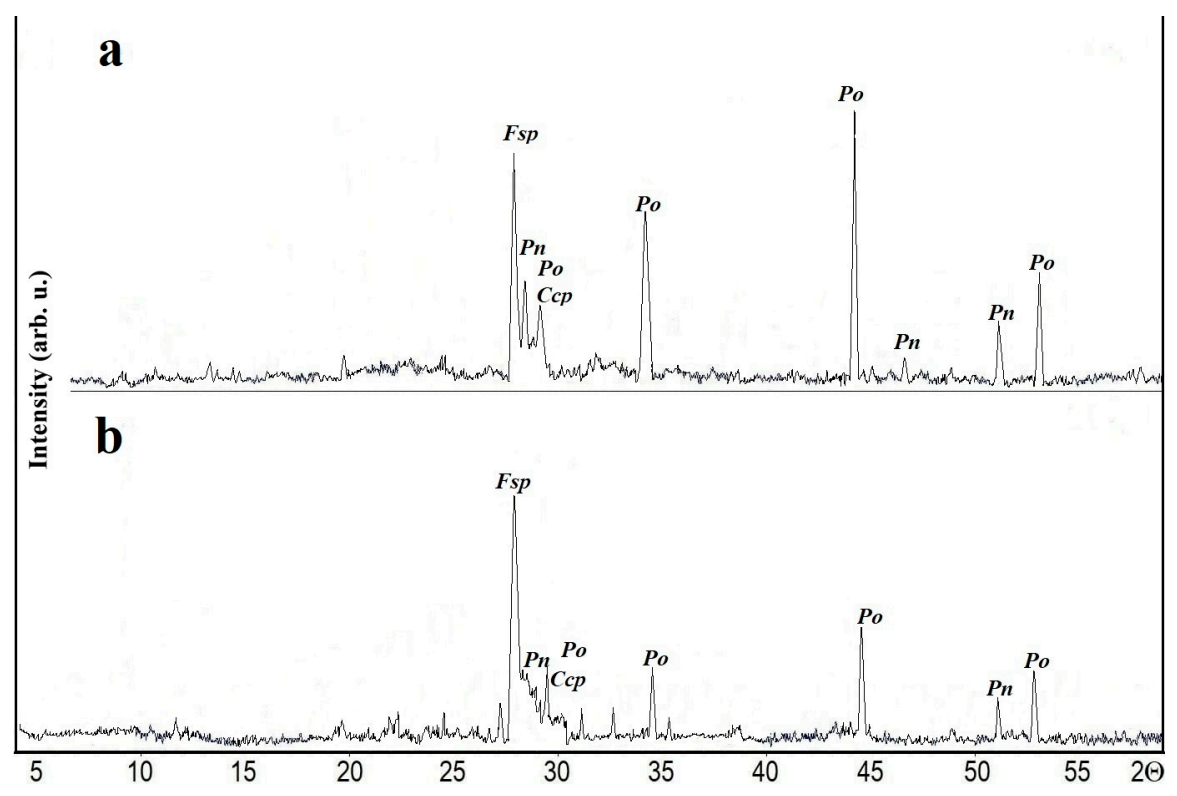

Figure 4. X-ray diffraction pattern of the Nud II samples: (a) feed ore; (b) ore after leaching. Fsp: feldspar; Po: pyrrhotite; Pn: pentlandite; Ccp: chalcopyrite.

The $\mathrm{pH}$ value of the pregnant liquors varied from 1.8 to 2.3 , while the redox potential ranged from 488 to $608 \mathrm{mV}$. The concentration of ferric iron, which at the beginning of the experiment was $9 \mathrm{~g} / \mathrm{L}$, increased by the end of the experiment to $16.4 \mathrm{~g} / \mathrm{L}$, while the concentration of ferrous iron decreased from $1.9 \mathrm{~g} / \mathrm{L}$ to $0.9 \mathrm{~g} / \mathrm{L}$. The sulfur content in the solid phase decreased by $34.6 \%$, which is three times higher than in the Allarechensk TD ore (Table 2).

Table 2. Chemical composition of the Nud II ore.

\begin{tabular}{|c|c|c|c|c|c|c|c|c|c|c|c|c|}
\hline & $\mathrm{Na}_{2} \mathrm{O}$ & $\mathrm{MgO}$ & $\mathrm{Al}_{2} \mathrm{O}_{3}$ & $\mathrm{SiO}_{2}$ & $S$ & $\mathrm{CaO}$ & $\mathrm{TiO}_{2}$ & $\mathrm{Cr}_{2} \mathrm{O}_{3}$ & $\mathrm{Fe}_{2} \mathrm{O}_{3}$ & $\mathrm{CoO}$ & $\mathrm{NiO}$ & $\mathrm{CuO}$ \\
\hline Feed ore & 0.02 & 7.30 & 2.30 & 32.3 & 14.9 & 4.60 & 0.30 & 0.14 & 33.2 & 0.26 & 2.40 & 2.20 \\
\hline Ore after leaching & 0.06 & 7.53 & 3.00 & 40.0 & 9.75 & 4.77 & 0.38 & 0.18 & 30.5 & 0.24 & 1.40 & 1.70 \\
\hline
\end{tabular}

\section{Conclusions}

Laboratory tests demonstrated the high performance of heap bacterial leaching in the processing of natural and anthropogenic copper-nickel ores. The leaching of non-ferrous metals from the Nud II ore was particularly intense. This is probably due to the structural features of the ore from that specific deposit-when grinding, the sulfide grains unlocked better and became available for leaching. The bacterial strain used demonstrated its ability to function effectively at low $\mathrm{pH}$ values of the solution and high metal concentrations.

The main reason for the inhibition of the ore leaching process in the experiment can be attributed to particle sintering and clogging. This problem can be solved by mixing the ore layers in order to improve their permeability.

The use of the heap leaching method makes it possible to process mineral feeds, for which no market demand currently exists. The recovery of such minerals allows the acquisition of additional economic benefits with a reduction of their negative impacts on the environment.

Author Contributions: Conceptualization, E.Y., N.F., E.S., A.K., D.M. and A.G.; methodology, E.Y., N.F., E.S., A.K., D.M. and A.G.; software, E.Y., N.F., E.S., A.K., D.M. and A.G.; validation, E.Y., N.F., E.S., A.K., D.M. and A.G.; formal analysis, E.Y., N.F., E.S., A.K., D.M. and A.G.; investigation, E.Y., N.F., E.S., A.K., D.M. and A.G.; resources, E.Y., N.F., E.S., A.K., D.M. and A.G; data curation, E.Y., N.F., E.S., A.K., D.M. and A.G.; writing—original draft preparation, E.Y., N.F., E.S., A.K., D.M. and 
A.G.; writing—review and editing, E.Y., N.F., E.S., A.K., D.M. and A.G.; visualization, E.Y., N.F., E.S., A.K., D.M. and A.G.; supervision, N.F. and D.M.; project administration, E.Y. and A.G.; funding acquisition, D.M. All authors have read and agreed to the published version of the manuscript.

Funding: This research was funded by the Russian government nos. 0226-2019-0011, public contract AAAA-A18-118021490070-5 and partially supported by the RFBR grant 19-05-50065 Microcosm.

Data Availability Statement: All the data used in this study can be found from the published manuscript.

Conflicts of Interest: The authors declare no conflict of interest.

\section{References}

1. Orsoev, D.A. Copper-nickel deposits of the Kola nickel province (Murmansk region, Russia). Earth Sci. Subsoil Use 2011, 38, 47-56.

2. Yakovlev, B.A. Climate of Murmansk Region; Murmansk Book Press: Murmansk, Russia, 1961; pp. 1-86.

3. Dauvalter, V.A.; Kashulin, N.A. Ecological and economic assessment of the need to extract bottom sediments from Lake Nudyavr, Monchegorsk district, Murmansk region. Vestn. MSTU 2011, 14, 884-891.

4. Goryachev, A.A.; Svetlov, A.V. The research of heap leaching method necessity on example of low-grade copper-nickel ores in the Murmansk region. Miner. Technol. 2018, 19, 217-224.

5. Schiers, D.V.; Collison, D.M.; Watling, H.R. Life in heaps: A review of microbial responses to variable acidity in sulfide mineral bioleaching heaps for metal extraction. Res. Microbiol. 2016, 167, 576-586. [CrossRef] [PubMed]

6. Domic, E.M. A review of the development and current status of copper bioleaching operations in Chile: 25 years of successful commercial implementation. Biomining 2007, 81-95. [CrossRef]

7. Watling, H.R. The bioleaching of sulphide minerals with emphasis on copper sulphides-A review. Hydrometallurgy 2006, 84, 81-108. [CrossRef]

8. Akcil, A.; Ciftci, H.; Deveci, H. Role and contribution of pure and mixed cultures of mesophiles in bioleaching of a pyritic chalcopyrite concentrate. Miner. Eng. 2007, 20,310-318. [CrossRef]

9. Halinen, A.K.; Rahunen, N.; Kaksonen, A.H.; Puhakka, J.A. Heap bioleaching of a complex sulfide ore: Part I: Effect of pH on metal extraction and microbial composition in pH controlled columns. Hydrometallurgy 2009, 98, 92-100. [CrossRef]

10. Halinen, A.K.; Rahunen, N.; Kaksonen, A.H.; Puhakka, J.A. Heap bioleaching of a complex sulfide ore: Part II. Effect of temperature on base metal extraction and bacterial compositions. Hydrometallurgy 2009, 98, 101-107. [CrossRef]

11. Banerjee, I.; Burrell, B.; Reed, C.; West, A.C.; Banta, S. Metals and minerals as a biotechnology feedstock: Engineering biomining microbiology for bioenergy applications. Curr. Opin. Biotechnol. 2017, 45, 144-155. [CrossRef] [PubMed] 